dr inz. Zygmunt Marciniak

dr ini. Ireneusz Pielecha

dr inż. Jacek Pielecha

Instytut Pojazdów Szynowych ,TABOR”

\title{
Wymagania i wytyczne dla lekkich materiałów konstrukcyjnych o minimalnym oddziaływaniu na środowisko naturalne
}

\begin{abstract}
$W$ artykule zaprezentowano przeglad lekkich materiałów konstrukcyjnych ze stopów metali lekkich (zwłaszcza stopów aluminium) oraz kompozytów (wysokowytrzymałych tworzyw sztucznych) majacych zastosowanie $w$ lekkich konstrukcjach pojazdów drogowych i szynowych. Zaprezentowano tendencje w produkcji materiałów lekkich ze szczególnym uwzględnieniem ograniczenia kosztów $w$ ich wytwarzaniu oraz ograniczeniu ich oddziaływania na środowisko naturalne.

Wskazano ponadto na ekonomiczne aspekty $w$ procesie recyklingu $i$ utylizacji tych materiatów jako szansa w ograniczeniu szkodliwego oddziaływania zastosowanych lekkich materiatów na środowisko naturalne w tym ograniczenie emisji substancji szkodliwych do atmosfery oraz zmniejszenie tzw. efektu cieplarnianego.

Artykut powstat $w$ ramach projektu rozwojowego $n r$ 100047/06/2009 pt.: „Konstrukcja pojazdu szynowego z zastosowaniem najnowszych lekkich materiałów $o$ wysokich parametrach wytrzymatościowych $i$ o minimalnym oddzialywaniu na środowisko naturalne".
\end{abstract}

\section{Wprowadzenie}

Przemysł środków transportu (w tym motoryzacyjny i kolejowy) przymierza się do dużych zmian w zakresie wykorzystywania lekkich materiałów w konstrukcji pojazdów, aby dostosować się do obowiązujących przepisów w ochronie środowiska. W wielu krajach na świecie obowiązują przepisy nakazujące zmniejszenie emisji dwutlenku węgla $\left(\mathrm{CO}_{2}\right)$. Regulacje te wprowadziły wymóg obniżenia masy pojazdów. Ciężkie materiały wykorzystywane w niektórych podzespołach zastapiono ich lżejszymi odpowiednikami. Powodem zmian jest fakt, że to właśnie masa pojazdu ma bezpośredni wpływ na zużycie paliwa.

$\mathrm{Z}$ nowej analizy globalnej firmy doradczej Frost \& Sullivan ujętej w pracy pt.: „Dominujące tendencje w zakresie zamienników materiałów i substancji chemicznych $\mathrm{w}$ procesie zmniejszania ciężaru pojazdów mechanicznych" [2, 13] wynika, że w $2010 \mathrm{r}$. globalny rynek lekkich materiałów zanotował przychody w wysokości 38 mld $\$$ i przewiduje się, że w 2017 r. będzie to $95,34 \mathrm{mld} \$$.

Główne działania podczas tworzenia konstrukcji lekkiej dotyczą zminimalizowania jej masy własnej pod warunkiem, że nie ogranicza się funkcji i czasu pracy tej konstrukcji. Możliwe jest określenie strategii tworzenia konstrukcji lekkich, których charakterystyczne cechy dają się ująć jako [10]:

- strategia materiałowa, polegająca na zastąpieniu pierwotnego materiału materiałem o mniejszej masie właściwej z możliwie najwyższymi
- wskaźnikami użytkowymi (dotyczy to np. zastąpienia materiałów stalowymi wysokowytrzymałymi stopami aluminium lub kompozytami włóknistymi),

- strategia postaciowa, dotycząca dostosowanego do występującego obciążenia rozmieszczenia materiału w strukturze nośnej (tzn. umacniania obszarów poddawanych wyższym obciążeniom, a redukowaniu materiału w obszarach mniej eksploatowanych przez zmniejszanie grubości ścianek czy użycie odpowiednich geometrii profili),

- strategia wytwórcza, wykorzystująca wszelkie możliwości technologiczne dla zapewnienia integracji funkcji przy możliwie najmniejszym zastosowaniu materiału i zminimalizowaniu miejsc połączeń,

Z każdą wymienioną strategią wiążą się całkowicie indywidualne koszty realizacji konstrukcji i technologii. Każdemu realizowanemu stopniowi lekkości konstrukcji (definiowanej jako odwrotność masy) są w budowie pojazdów i maszyn często przypisywane przedziały kosztów, które przeważnie dają ograniczoną swobodę działania. Koszty całkowite charakteryzują się na ogół przebiegiem wykładniczym z teoretycznym minimum, stanowiącym rozsądne gospodarczo rozwiązanie (rys. 1). Wskutek istnienia bezpośredniego związku między masą wyrobu a poziomem kosztów, koszty całkowite $\mathrm{z}$ reguły wzrastają nadproporcjonalnie wraz ze zwiększeniem się stopnia lekkości konstrukcji. 


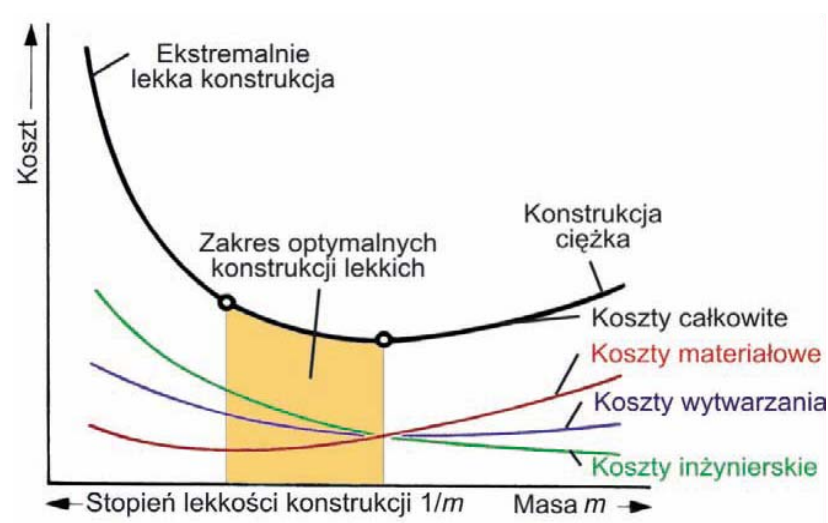

Rys.1. Zależność kosztów od masy konstrukcji lekkiej [10]

Do materiałów wykorzystywanych w konstrukcjach lekkich zalicza się materiały o masie właściwej (gęstości) $\rho>4500 \mathrm{~kg} / \mathrm{m}^{3}$ i materiały typowo lekkie o masie właściwej $\rho<4500 \mathrm{~kg} / \mathrm{m}^{3}$ [3]. Do typowo lekkich materiałów konstrukcyjnych zalicza się wysoko wytrzymałe stopy metali lekkich: aluminium, magnezu, tytanu i berylu, materiały kompozytowe wzmacniane głównie włóknami węglowymi i szklanymi, jak też aramidowymi, spienione materiały metalowe i ceramiczne, kompozyty metalowe $\mathrm{z}$ materiałami spienionymi oraz drewno, a zwłaszcza balsę o masie właściwej od $400 \mathrm{~kg} / \mathrm{m}^{3}$ do 1800 $\mathrm{kg} / \mathrm{m}^{3}$.

\section{Przegląd i zastosowanie materiałów lekkich stosowanych w środkach transportu}

Jako materiał konstrukcyjny, używany przy budowie nadwozi pojazdów szynowych dominują stale, ale coraz częściej pojawia się tworzywo sztuczne (tab. 1). Dotyczy to zarówno wnętrza z płaskich wykładzin z Unilamu (czyli żywic melaminowych na nośniku papierowym), jak i wielu istotnych, tradycyjnie stalowych części zewnętrznych, które zastępowane są kształtowymi elementami z kompozytów poliestrowych, wzmacnianych włóknem szklanym (tab. 2).

Konstrukcja kabin sterowniczych może być wykonana na bazie struktury szkieletu z profili stalowych, które stanowią integralne wzmocnienie dla jednowarstwowego poszycia z kompozytu poliestrowego, wzmacnianego włóknem szklanym. Z kolei kabina kolejowych zespołów trakcyjnych najczęściej zbudowana jest w sposób bardziej skomplikowany, jako konstrukcja „sandwiczowa” (rys. 2), zawierająca specjalne, zintegrowane w strukturze kompozytu, przestrzenne wzmocnienia stalowe, służące do montażu wyposażenia kabiny, osprzętu, jak również zapewniające połączenie gotowej kabiny z ramą nośną $\mathrm{i}$ szkieletem przyszłej jednostki [6].

Największe zastosowanie w przemyśle transportowym znajdują obecnie kompozyty polimerowe (ok. $90 \%$ ). Typowe zbrojenie polimerów to włókna szklane, węglowe i aramidowe. Wiele spośród znanych polimerów termoplastycznych zawiera celowo
Materialy stosowane w przemyśle środków transportu

Tablica 1

\begin{tabular}{|c|c|c|}
\hline Materiały & $\begin{array}{l}\text { Skład che- } \\
\text { miczny }\end{array}$ & Obszar zastosowań \\
\hline $\begin{array}{l}\text { Stale typu ,,mara- } \\
\text { ging” }\end{array}$ & $\begin{array}{c}? 0,03 \% \mathrm{C} \\
8,5-12,5 \% \\
\mathrm{Co} \\
18 \% \mathrm{Ni} \\
3-5 \% \mathrm{Mo}, \\
0,2-1,8 \% \mathrm{Ti}\end{array}$ & $\begin{array}{c}\text { elementy konstrukcyjne } \\
\text { w technice lotniczej, w } \\
\text { budowie okrętów oraz } \\
\text { w przemyśle zbroje- } \\
\text { niowym }\end{array}$ \\
\hline Hydronalia & $\begin{array}{c}93,2-99,5 \% \\
\mathrm{Al}, \\
0,4-5,6 \% \mathrm{Mg}, \\
\text { poniżej } 0,5 \% \\
\mathrm{Si}\end{array}$ & $\begin{array}{c}\text { średnio obciążone } \\
\text { elementy w przemyśle } \\
\text { okrętowym i lotniczym }\end{array}$ \\
\hline Spienione aluminium & & $\begin{array}{l}\text { elementy stref zgniotu } \\
\text { w pojazdach drogowych } \\
\text { i szynowych }\end{array}$ \\
\hline $\begin{array}{l}\text { Kompozyty zbrojone } \\
\text { włóknami aramido- } \\
\text { wymi (Kevlar) }\end{array}$ & & $\begin{array}{c}\text { elementy konstrukcyjne } \\
\text { statków kosmicznych i } \\
\text { samolotów }\end{array}$ \\
\hline $\begin{array}{l}\text { Kompozyty o osno- } \\
\text { wie metalowej }\end{array}$ & & $\begin{array}{l}\text { lekkie elementy silnika } \\
\text { i podwozia pojazdów } \\
\text { drogowych i szynowych }\end{array}$ \\
\hline
\end{tabular}

wprowadzoną fazę zdyspergowaną, co zalicza je do grupy materiałów kompozytowych. Przykładem mogą być elementy maszyn wzmocnione ciętymi włóknami szklanymi: np. małe kola zębate $\mathrm{z}$ poliamidu (nylonu), panewki łożysk ślizgowych $\mathrm{z}$ teflonu, nadproża, zderzaki karoserii z polipropylenu wzmocnionego włóknami szklanymi ciagłymi (40\%) [3].

Typowe kompozyty konstrukcyjne z polimerów termoutwardzalnych to laminaty (kompozyty warstwowe) poliestrowe wzmocnione ciagłym lub ciętym włóknem szklanym stosowane do budowy kadłubów łodzi i małych jednostek pływających jak również małych samolotów, samochodów, cystern wiatraków itd. We wszystkich tych zastosowaniach w przypadku elementów dużych i silnie obciążonych m.in. ster pionowy, wysokości, oprofilowanie skrzydeł, łopaty wirnika helikoptera, duże $(50-80 \mathrm{~m})$ kadłuby okrętów, wzmocnienie szklane zastępowane jest częściowo lub całkowicie przez włókna węglowe oraz aramidowe w osnowie żywicy epoksydowej. Często jest to kombinacja tych trzech rodzajów włókien (kompozyt hybrydowy). Przykładem kompozytu o osnowie elastomeru jest poliizopren wzmocniony nanocząstkami $(20-30 \quad \mathrm{~nm})$ sadzy stosowany do budowy opon samochodowych.

Kompozyty o osnowie metalowej są W większości drogie dlatego ich zakres zastosowań jest wciąż ograniczony. Najbardziej znane są odlewane lub spiekane elementy z kompozytów o osnowie stopów Al wzmacniane cząstkami węglika krzemu (SiC) lub $\mathrm{Al}_{2} \mathrm{O}_{3}$, takie jak tarcze hamulcowe, tłoki silników spalinowych, bloki silnikowe, ramy rowerów raz końcówki kijów golfowych i ostrza łyżew hokejowych z Ti/TiC (tab. 3). 


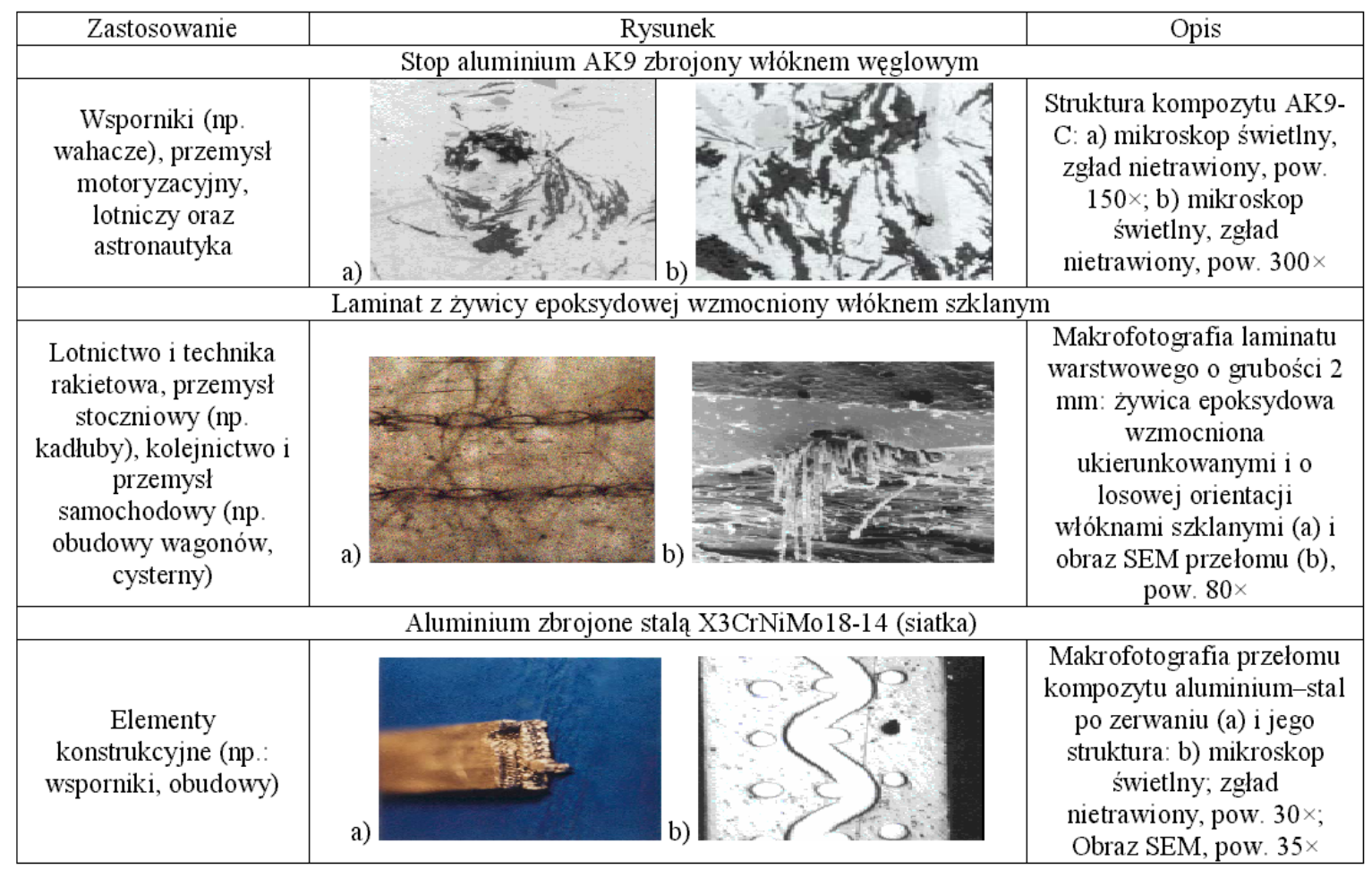

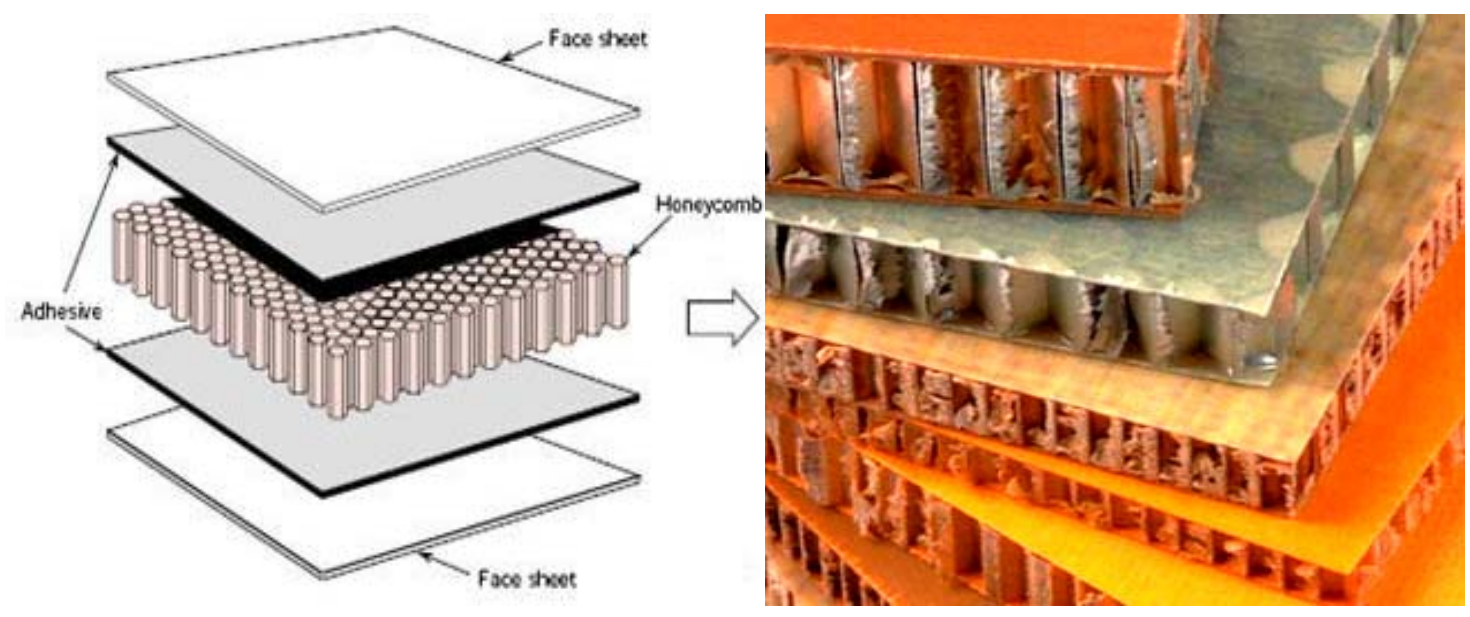

Rys.2 Kompozyt warstwowy typu ,sandwich” [12, 13]

\begin{tabular}{|c|c|c|}
\hline Obszar & Typowe wyroby & Materiały \\
\hline $\begin{array}{c}\text { Elektronika energe- } \\
\text { tyka }\end{array}$ & $\begin{array}{c}\text { kondensatory, izolatory, nadprzewodniki, } \\
\text { rdzenie cewek, magnesy, osłony }\end{array}$ & $\begin{array}{c}\text { tytaniany, } \mathrm{Al}_{2} \mathrm{O}_{3}, \text { ferryty, } \\
\text { BeO, węgliki, azotki }\end{array}$ \\
\hline Budowa silników & $\begin{array}{c}\text { tłoki, tuleje cylindrowe, komory wstępne- } \\
\text { go spalania, zespoły popychaczy zaworów, } \\
\text { wirniki i łożyska turbosprężarek }\end{array}$ & $\begin{array}{c}\text { ceramika tlenkowa, wę- } \\
\text { gliki, azotki }\end{array}$ \\
\hline Obróbka materiałów & $\begin{array}{c}\text { noże tokarskie, narzędzia cierne, pasty } \\
\text { polerskie, elementy mielące }\end{array}$ & węgliki, azotki \\
\hline Inżynieria chemiczna & czujniki, złoża katalizatorów & $\begin{array}{c}\text { porcelana, ceramika } \\
\text { tlenkowa, węgliki, azotki }\end{array}$ \\
\hline
\end{tabular}


Zaawansowane kompozyty np. o osnowie stopu Ti lub Al i wzmocnieniu z włókien węglowych lub boru stosuje się głównie w lotnictwie i kosmonautyce. $Z$ włókien węglowych (rys. 3) w osnowie Al wytwarza się podłużnice kadłuba samolotu, ze stopu Ti wzmocnionego włóknami boru formuje się łopatki kompresora silnika lotniczego a korbowody silnika spalinowego można otrzymać z kompozytu Ti/ciągłe włókna SiC.

Pracujące w ekstremalnie wysokich temperaturach i przy wysokich obciążeniach łopatki turbiny silnika odrzutowego np. ze stopu niklu mogą być wzmocnione fazą TiC. Zastosowania kompozytów o osnowie ceramicznej obejmują narzędzia skrawające $\mathrm{z}$ dużymi prędkościami np. $\mathrm{z} \quad \mathrm{Al}_{2} \mathrm{O}_{3}$ wzmocnionego wiskerami $\mathrm{SiC}$, elementy silników spalinowych: zawory wlotowe (Nissan), pierścienie tłokowe (Isuzu), komora spalania, wirniki, łopatki turbin spalinowych (Toyota) - z kompozytu SiC/SiC.

Kompozyt węgiel/węgiel (z powłoką ochronną $\mathrm{SiC})$ wytrzymuje ekstremalne temperatury $2600^{\circ} \mathrm{C}$ i jest wykorzystywany w takich elementach jak dziób wahadłowca kosmicznego, wykładzina komory spalania i dysza wylotowa gazów silnika odrzutowego, tarcze hamulcowe.

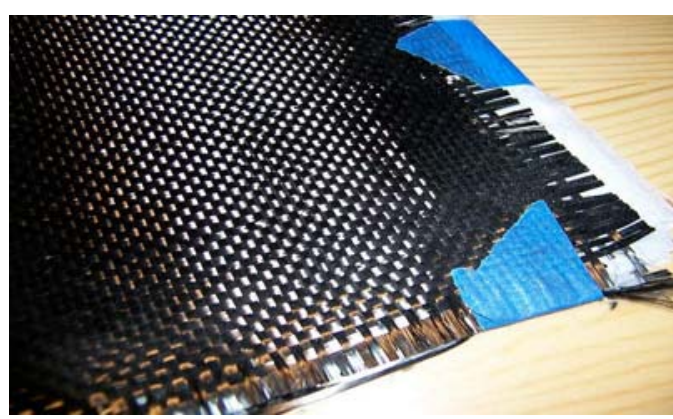

Rys.3 Tkanina z włókna węglowego

\section{Właściwości materiałów lekkich i kompozyto- wych}

Włókna stosowane do zbrojenia kompozytów można podzielić na pięć grup w zależności od rodzaju materiału. Są to włókna nieorganiczne, grafitowe, polimerowe, ceramiczne i metalowe. Spośród cech fizycznych charakteryzujących włókna najczęściej podaje się średnicę, gęstość, wytrzymałość na rozciąganie i moduł sprężystości wzdłużnej (Younga).

Przy wyborze materiału $\mathrm{z}$ jakiego jest wykonane włókno, bardzo często bierze sie pod uwagę tzw. moduł sprężystości i wytrzymałość właściwa, które przedstawiają te charakterystyki odniesione do gęstości materiału. Wytrzymałość właściwa to wyrażona w km długość włókna przy której niszczy się ono pod własnym ciężarem. Moduł właściwy i wytrzymałość właściwa nowoczesnych włókien stosowanych w materiałach kompozytowych są wielokrotnie większe niż włókien metalowych, co jest powodem ich szerokiego stosowania w przemyśle lotniczym i kosmicznym, gdzie szuka sie materiałów o wysokiej wytrzymałości i jednocześnie najlżejszych. Właściwości różnych rodzajów włókien, należących do wymienionych pięciu grup, zestawiono w tabeli 4.

Osnowy stosowane w kompozytach włóknistych dzieli sie pod względem materiału na polimerowe, metalowe i ceramiczne (tab. 5). Osnowy polimerowe są stosowane najczęściej, ponieważ są tanie i posiadają właściwości fizykochemiczne wystarczające dla większości warunków pracy kompozytu. Jedynie w konstrukcjach pracujących w bardzo wysokich temperaturach lub $\mathrm{w}$ wyjątkowo agresywnym środowisku stosuje sie kompozyty z osnową metalową i ce-

Tablica 4

Wlaściwości różnych rodzajów włókien $[7,9,11]$

\begin{tabular}{|c|c|c|c|c|c|c|}
\hline Materiał & $\begin{array}{l}\text { Średnica } \\
\text { [um] }\end{array}$ & $\begin{array}{l}\text { Gęstość } \\
{\left[\mathrm{kg} / \mathrm{m}^{3}\right]}\end{array}$ & $\begin{array}{c}\text { Moduł sprężysto- } \\
\text { ści wzdłużnej } \\
{[\mathrm{GPa}]}\end{array}$ & $\begin{array}{c}\text { Wytrzymałość } \\
\text { na rozciaganie } \\
{[\mathrm{MPa}]}\end{array}$ & $\begin{array}{l}\text { Moduł spręży- } \\
\text { stości właści- } \\
\text { wy }[\mathrm{km}]\end{array}$ & $\begin{array}{l}\text { Wytrzymałość } \\
\text { właściwa }[\mathrm{km}]\end{array}$ \\
\hline \multicolumn{7}{|c|}{ Druty metalowe } \\
\hline stal & $20-1500$ & 7800 & $180-200$ & $1500-4400$ & 2560 & 56,4 \\
\hline aluminium & 150 & 2700 & 69 & 290 & 2550 & 10,7 \\
\hline tytan & $100-800$ & 4500 & 120 & $1400-1500$ & 2670 & 33,3 \\
\hline beryl & $50-500$ & 1800 & $240-310$ & $1100-1450$ & 17200 & 80,5 \\
\hline \multicolumn{7}{|c|}{ Włókna nieorganiczne } \\
\hline szkło E & 7 & 2540 & 70 & 3450 & 2756 & 140,8 \\
\hline szkło S & 15 & 2500 & 86 & 4500 & 3440 & 180,0 \\
\hline bor & 130 & 2600 & 400 & 3500 & 15385 & 134,6 \\
\hline \multicolumn{7}{|c|}{ Włókna grafitowe } \\
\hline grafit HS & $5-11$ & 1800 & $150-250$ & $3000-7000$ & 13800 & 390,0 \\
\hline grafit HM & $5-11$ & 1900 & 400 & 1800 & 21000 & 94,7 \\
\hline węgiel & $5-11$ & 1400 & 150 & 1700 & 10700 & 121,4 \\
\hline \multicolumn{7}{|c|}{ Włókna polimerowe } \\
\hline aramidowe & $12-15$ & $\begin{array}{c}1400- \\
1470\end{array}$ & $140-180$ & $3500-5500$ & 12800 & 390,0 \\
\hline polietylenowe & $20-40$ & 970 & $120-170$ & $2600-3300$ & 17500 & 310,0 \\
\hline \multicolumn{7}{|c|}{ Włókna ceramiczne } \\
\hline $\begin{array}{c}\text { węglik krzemu } \\
\mathrm{SiC}\end{array}$ & $10-140$ & $\begin{array}{c}2800- \\
3100\end{array}$ & 250 & 3000 & 8928 & 107,1 \\
\hline korund $\mathrm{Al}_{2} \mathrm{O}_{3}$ & $5-20$ & 3700 & $350-380$ & 1700 & 10270 & 45,9 \\
\hline
\end{tabular}


ramiczną. Kompozyty takie są jednak bardzo drogie, ze względu na złożony proces ich produkcji.

Podobne zalety jak w przypadku materiałów ceramicznych wykazują osnowy metalowe. Dodatkowo maja lepsza odporność na pękanie i zmęczenie, a także lepiej przewodzą ciepło. Dopuszczalna temperatura pracy wynosi do 1000 stC. Osnowy metalowe wykonywane są najczęściej ze stopów różnych metali, takich jak aluminium tytan magnez i miedź.

Kompozyty mają wiele zalet $\mathrm{w}$ porównaniu $\mathrm{z}$ konwencjonalnymi materiałami konstrukcyjnymi. Do najważniejszych należy duża sztywność i wytrzymałość właściwa, co przekłada sie na znaczącą wytrzymałość przy bardzo małym ciężarze własnym. Porównanie w tym zakresie niektórych kompozytów z materiałami konwencjonalnymi podano $\mathrm{w}$ tabeli $6 \mathrm{i}$ na rysunkach 4 i 5 . Cecha ta powoduje, że kompozyty wykorzystuje się wszędzie tam, gdzie główne znaczenie ma mały ciężar i duża wytrzymałość (przemysł kosmiczny, lotniczy, środki transportu drogowego i szynowego).
Podstawowa wada kompozytów, która w istotny sposób ogranicza powszechność stosowania tego typu materiałów jest cena. Koszt włókien szklanych wynosi 2-16 \$/kg, włókien węglowych 16-80 \$/kg, żywica epoksydowa kosztuje $3 \$ / \mathrm{kg}$, a gotowe kompozyty w postaci tzw. taśm prepreg - szkło/epoksyd $24 \$ / \mathrm{kg}$, węgiel/epoksyd 24-120 \$/kg. Dla porównania koszt stali wynosi $0,4-2 \$ / \mathrm{kg}$, a aluminium $1,2 \div 2$ $\$ / \mathrm{kg}$. Powyższe ceny $-\mathrm{z}$ racji braku tego typu danych $\mathrm{u}$ polskich dystrybutorów materiałów konstrukcyjnych - podano w dolarach amerykańskich za [5].

Jako uzupełnienie do przedstawionych możliwości eksploatacyjnych najczęściej wykorzystywanych materiałów konstrukcyjnych, do oceny ich przydatności do budowy konstrukcji lekkich mogą służyć tzw. wskaźniki użytkowości. W tabeli 7 zestawiono stosowane w praktyce wskaźniki użytkowości dostosowane do różnych rodzajów obciążeń. Wartości poszczególnych wskaźników odniesiono do stopów aluminium, co spowodowało, że porównanie jest wielokrotnie relatywizowane.

Właściwości materiałów na osnowy kompozytów [7, 9, 11]

Tablica 5

\begin{tabular}{|c|c|c|c|c|}
\hline Rodzaj osnowy & Gęstość $\left[\mathrm{kg} / \mathrm{m}^{3}\right]$ & $\begin{array}{c}\text { Moduł sprężysto- } \\
\text { ści wzdłużnej } \\
{[\mathrm{GPa}]}\end{array}$ & $\begin{array}{c}\text { Wytrzymałość } \\
\text { na rozciaganie } \\
{[\mathrm{MPa}]}\end{array}$ & $\begin{array}{c}\text { Dopuszczalna } \\
\text { temperatura }\left[{ }^{\circ} \mathrm{C}\right]\end{array}$ \\
\hline $\begin{array}{c}\text { Polimerowa termo- } \\
\text { utwardzalna: }\end{array}$ & & & & \\
epoksyd & $1200-1400$ & $2,5-5,0$ & $50-110$ & $80-215$ \\
fenol & $1200-1400$ & $2,7-4,1$ & $35-60$ & $70-150$ \\
poliester & $1100-1400$ & $1,6-4,1$ & $35-95$ & $60-150$ \\
$\begin{array}{c}\text { Polimerowa termo- } \\
\text { plastyczna }\end{array}$ & & & & \\
nylon & 1100 & $1,3-3,5$ & $55-90$ & $75-100$ \\
polietereterketon & 1300 & $3,5-4,4$ & 100 & $120-250$ \\
poliester & 1400 & $2,1-2,8$ & $55-60$ & $70-120$ \\
polietylen & 1000 & $0,7-1,4$ & $20-35$ & $50-80$ \\
Ceramiczna & & 250 & - & $1200-3500$ \\
weglik krzemu SiC & $2800-3100$ & $350-380$ & 440 & $1200-3500$ \\
korund Al2O3 & 3900 & 77 & 420 & 500 \\
Metalowa & 2800 & 105 & $940-1100$ & $800-1000$ \\
stopy aluminiowe & 4500 & 42 & 280 & $800-1000$ \\
stopy tytanowe & 1800 & - & $500-800$ & - \\
stopy magnezowe & 8000 & & & \\
stopy miedzi & & & & \\
\hline
\end{tabular}

Wlaściwości kompozytów i materiałów konwencjonalnych [7, 9, 11]

Tablica 6

\begin{tabular}{|c|c|c|c|c|c|c|}
\hline Materiał & $\begin{array}{c}\text { Gęstość } \\
{\left[\mathrm{kg} / \mathrm{m}^{3}\right]}\end{array}$ & $\begin{array}{c}\text { Moduł } \\
\text { sprężystości } \\
\text { wzdłużnej } \\
{[\mathrm{GPa}]}\end{array}$ & $\begin{array}{c}\text { Wytrzymałość } \\
\text { na rozciaganie } \\
{[\mathrm{MPa}]}\end{array}$ & $\begin{array}{c}\text { Moduł sprę- } \\
\text { żystości } \\
\text { właściwy } \\
{[\mathrm{km}]}\end{array}$ & $\begin{array}{c}\text { Wytrzymałość } \\
\text { właściwa }[\mathrm{km}]\end{array}$ & $\begin{array}{c}\text { Dopuszczalna } \\
\text { temperatura } \\
{\left[{ }^{\circ} \mathrm{C}\right]}\end{array}$ \\
\hline $\begin{array}{c}\text { Drewno świer- } \\
\text { kowe }\end{array}$ & 5500 & 9 & 39 & 1636 & 7,1 & łatwo palne \\
Stal węglowa & 7850 & 210 & $370-460$ & 2675 & 5,8 & $500-600$ \\
Stal stopowa & 7850 & 210 & $490-560$ & 2675 & 7,1 & $500-600$ \\
Aluminium & 2700 & 72 & 450 & 2667 & 16,7 & $150-250$ \\
Wegiel/ & $1300-1800$ & $130-200$ & $1300-3000$ & 11100 & 166,7 & $80-215$ \\
/epoksyd & $1300-1380$ & $75-95$ & $1380-2200$ & 6880 & 159,4 & $80-215$ \\
Aramid/ & 45 & $1200-3000$ & 2250 & 150,0 & $80-215$ \\
/epoksyd & $1500-2000$ & 45 & & \\
$\begin{array}{c}\text { Szkło/ } \\
\text { /Eepoksyd }\end{array}$ & & & & & \\
\hline
\end{tabular}




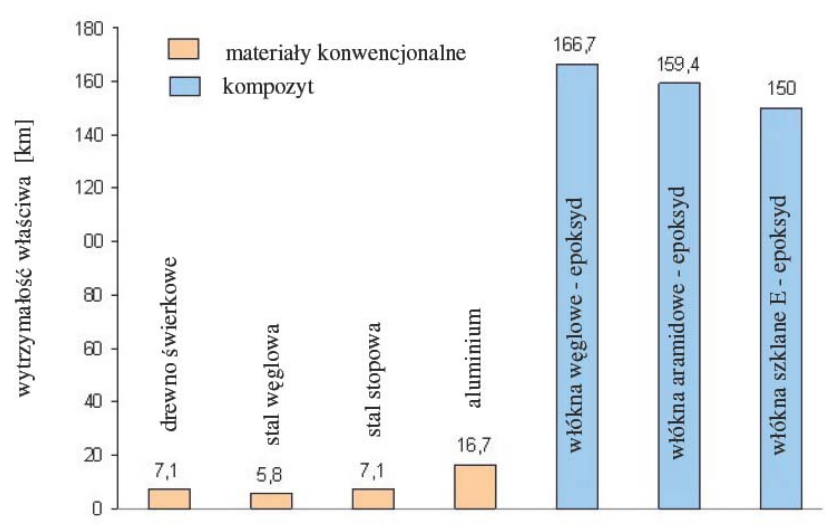

Rys. 4 Wytrzymałość właściwa dla materiałów konwencjonalnych i kompozytowych $[7,9,11]$

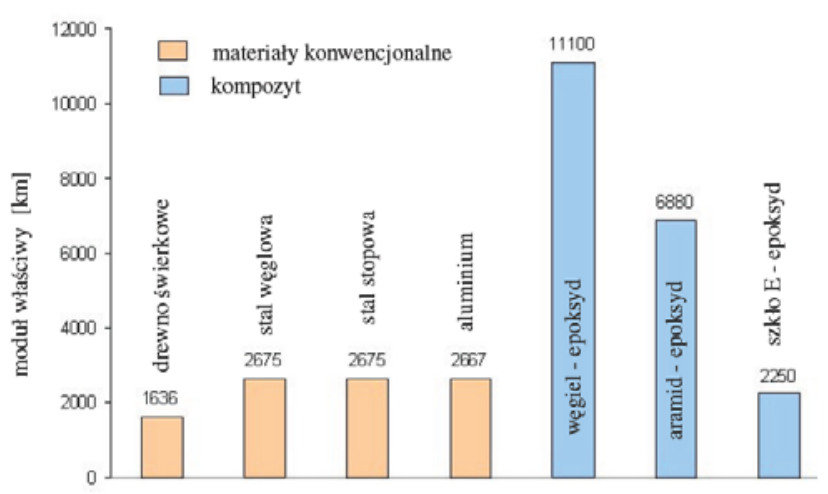

Rys. 5 Moduł sprężystości właściwy dla materiałów konwencjonalnych i kompozytowych $[7,9,11]$
Każdy ze wskaźników użytkowości podaje, o ile razy lżejsza (lub cięższa) geometrycznie jest podobna konstrukcja $\mathrm{z}$ rozpatrywanego materiału $\mathrm{w}$ porównaniu $\mathrm{z}$ wybranym materiałem odniesienia, tj. stopem aluminium. Według tabeli 7 , usztywnienie skrzydła samolotu wykonane z GFRP byłoby pod względem statecznej wytrzymałości na rozciaganie „lżejsze” o wskaźnik 7,65 niż ze stopu aluminium. Jednak pod względem sztywności podłużnej byłoby ono jeszcze tylko 0,67 razy tak ,lekkie”, a więc 1,49 razy „cięższe”. Dane zawarte w tabeli 7 pozwalają więc na bardzo dobre przyporządkowanie materiałów do określonej charakterystyki obciążenia i mogą służyć do szybkiego ich prawyboru.

Reasumując, aspekty materiałowe konstrukcji lekkich sprowadzają się ogólnie do wyboru materiału, który - w warunkach występujących obciążeń wyrobu - potrafi najlepiej się im przeciwstawiać (rys. 6). Dzięki temu w niektórych miejscach można zaoszczędzić na materiale, a więc i na masie wyrobu, w przypadku, gdy np. przekrój nośny będzie zmniejszony. Alternatywnie można obniżać masę konstrukcji przez zastosowanie materiału o mniejszej gęstości. Klasycznym przykładem stosowania tego rodzaju zamienników materiałowych jest dokonywane w branży samochodowej zastępowanie stali przez aluminium, magnez czy materiały kompozytowe.

Wskaźniki użytkowości służące ocenie przydatności wybranych materiałów do budowy konstrukcji lekkich odniesione do stopów aluminium (wg [4])

Tablica 7

\begin{tabular}{|c|c|c|c|c|c|c|c|c|c|}
\hline \multirow{3}{*}{$\begin{array}{l}\text { Właściwość odnie- } \\
\text { siona do: }\end{array}$} & \multirow{3}{*}{$\begin{array}{l}\text { Wskaźnik } \\
\text { użytkowości }\end{array}$} & \multicolumn{8}{|c|}{ Rodzaj materiału } \\
\hline & & \multicolumn{3}{|c|}{ Stopy metali } & \multirow{2}{*}{ Stal } & \multicolumn{3}{|c|}{ Kompozyty } & \multirow{2}{*}{ Drewno } \\
\hline & & $\mathrm{Al}$ & $\mathrm{Mg}$ & $\mathrm{Ti}$ & & CFRP & GFRP & AFRP & \\
\hline $\begin{array}{l}\text { Wytrzymałość - } \\
\text { rozciaganie, ściskanie }\end{array}$ & $\frac{R_{m}}{g \cdot \rho}$ & 1 & 1,16 & 1,5 & 0,6 & 3,45 & 7,65 & 9,36 & 1,35 \\
\hline $\begin{array}{l}\text { Sztywność - rozcią- } \\
\text { ganie, ściskanie }\end{array}$ & $\frac{E}{g \cdot \rho}$ & 1 & 1 & 0,94 & 1,03 & 3,09 & 0,67 & 0,91 & 0,93 \\
\hline $\begin{array}{l}\text { Sztywność - ścinanie } \\
\text { przy skręcaniu }\end{array}$ & $\frac{G}{g \cdot \rho}$ & 1 & 1,06 & 0,93 & 1,06 & 1,11 & 0,32 & 0,15 & - \\
\hline $\begin{array}{l}\text { Sztywność - wybo- } \\
\text { czenie prętów }\end{array}$ & $\sqrt{\frac{E}{g \cdot \rho}}$ & 1 & 1 & 0,97 & 1,2 & 1,76 & 0,82 & 0,95 & 0,96 \\
\hline $\begin{array}{l}\text { Sztywność - wybo- } \\
\text { czenie i zginanie płyt }\end{array}$ & $\sqrt[3]{\frac{G}{g \cdot \rho}}$ & 1 & 1 & 0,98 & 1,01 & 1,46 & 0,87 & 0,97 & 0,97 \\
\hline $\begin{array}{l}\text { Sprężysta zdolność } \\
\text { pochłaniania energii }\end{array}$ & $\frac{\mathrm{R}_{\mathrm{p} 0,2}^{2}}{\mathrm{E}}$ & 1 & 1,55 & 4,54 & 2,08 & 2,29 & 9,14 & 19,78 & 0,47 \\
\hline Udarność & $\mathrm{A}$ & 1 & 2,5 & 1,5 & 2,5 & 0,2 & 0,75 & 0,2 & 0,2 \\
\hline $\begin{array}{c}\text { Wytrzymałość zmę- } \\
\text { czeniowa } \\
\mathrm{R}=-1 ; \mathrm{N}_{\mathrm{G}}=10^{6}\end{array}$ & $\frac{\sigma_{\mathrm{m}}}{\mathrm{g} \cdot \rho}$ & 1 & 1,2 & 2,2 & 1,3 & 2,8 & 1,7 & 3,2 & 1,2 \\
\hline $\begin{array}{r}\mathrm{CF} \\
\mathrm{GF} \\
\mathrm{AFR}\end{array}$ & $\begin{array}{l}\text { Wartości }>1 \\
\text { - kompozyt z } \\
\text { - kompozyt } \\
\text { kompozyt z }\end{array}$ & & lime & $\begin{array}{l}\text { wą } \\
\text { ą wz }\end{array}$ & $\begin{array}{l}\text { niż } \\
\text { cniar }\end{array}$ & $\begin{array}{l}\text { y alum } \\
\text { fóknar } \\
\text { włókna } \\
\text { óknam }\end{array}$ & $\begin{array}{l}\text { Im. } \\
\text { veglow } \\
\text { szklany } \\
\text { amido }\end{array}$ & & \\
\hline
\end{tabular}




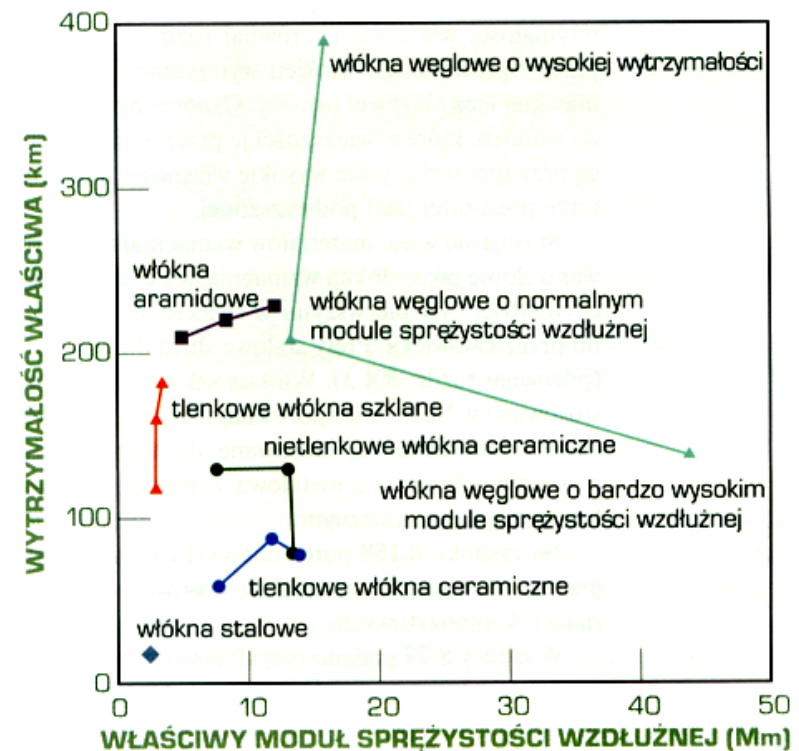

Rys.6 Porównanie wybranych własności mechanicznych włókien stosowanych do wzmacniania kompozytów [1]

\section{Wytyczne i wymagania dotyczące materiałów lekkich w zakresie oddziaływania na środowi- sko}

Aktualne wymagania dotyczące materiałów konstrukcyjnych wykorzystywanych $\mathrm{w}$ przemyśle środków transportu drogowego i szynowego to:

- tendencja do stosowania materiałów konstrukcyjnych o mniejszej gęstości oraz większej wytrzymałości i lepszych właściwościach użytkowych. Dzięki temu jest możliwe zmniejszenie masy pojazdu i ograniczenie zużycia paliwa (a więc także emisji dwutlenku węgla). Należy zaznaczyć, że ważnym aspektem tych przedsięwzięć jest założenie braku wpływu podejmowanych działań na bezpieczeństwo pojazdu (na pogorszenie istniejącego stanu bezpieczeństwa). Przykładami takich rozwiązań konstrukcyjnych są m.in. struktury warstwowe i przestrzenne materiałów (np. typu sandwich), umożliwiające nie tylko znaczne zmniejszenie masy konstrukcji z zachowaniem porównywalnych właściwości wytrzymałościowych, ale i uzyskanie świadomej anizotropii właściwości konstrukcji (np. w strefach zgniatania struktury w związku z jej awaryjnym niszczeniem). Coraz większe zastosowanie znajdują również materiały kompozytowe, umożliwiające uzyskanie nieosiągalnych dotychczas właściwości części poddawanych ekstremalnym obciążeniom (np. tarcze hamulcowe, tłoki itd.) [6].

- zastosowanie nowych materiałów konstrukcyjnych i eksploatacyjnych, technologii wytwarzania i obsługi pojazdów powinno przyczynić się do zwiększenia trwałości pojazdów i ich elementów oraz wydłużenia okresów
- międzynaprawczych. Wpływa to na zmniejszenie obciążenia środowiska materiałami odpadowymi, związanymi z obsługą i likwidacją zużytych pojazdów. Korzyścią jest również oszczędność surowców i energii potrzebnej do przetwarzania materiałów i wytwarzania części i zespołów pojazdów.

- nowe materiały konstrukcyjne oraz sama konstrukcja powinny być dostosowane do sprawnego recyklingu pojazdów. Ważną właściwością nowych materiałów staje się możliwie ich duża biodegradowalność. Analogiczne wymagania stawiane są również infrastrukturze transportu.

wymaga się - ze względów ekonomicznych - aby koszty materiałów i technologii elementów pojazdów i infrastruktury transportu oraz materiałów eksploatacyjnych były stosunkowo nieduże. To zadanie, głównie $\mathrm{w}$ związku z wyżej sformułowanymi wymaganiami, jest trudne do spełnienia. Wiele rozwiązań ekologicznych w motoryzacji wiąże się z dużymi kosztami i często przegrywa $\mathrm{z}$ rozwiązaniami mniej korzystnymi dla środowiska, lecz tańszymi.

\section{Recykling i utylizacja materiałów}

Istotą recyklingu jest ograniczenie oddziaływania przemysłu motoryzacyjnego (a dokładniej wyprodukowanych pojazdów) na środowisko. Najprościej można to ująć w postaci schematu wejść i wyjść $z$ systemu. Przez system określa się w tym przypadku proces powstawania i eksploatacji pojazdu. Przestrzeń poza systemem traktowana jest jako środowisko, które jest z jednej strony źródłem wejść do systemu (surowce i materiały niezbędne do produkcji), z drugiej - miejscem przeznaczenia wyjść z systemu (emisje do środowiska). Zadaniem recyklingu jest ograniczenie zarówno wejść (zmniejszenie poboru nowych surowców poprzez ponowne wykorzystywanie starych), jak i wyjść (ograniczenie odpadów).

Często, aczkolwiek nie zawsze, przetwarzanie materiałów pochodzących z utylizowanych pojazdów jest mniej energochłonne, niż wykonanie tego samego elementu nowego pojazdu z surowców pierwotnych. Oszczędność energii wynikająca z odzysku w porównaniu $\mathrm{z}$ energią, którą trzeba zużyć do wyprodukowania metalu z pierwotnego surowca zmienia się od $60 \%$ do $95 \%$ (tab. 8). W przypadku olejów, wyprodukowanie $1 \mathrm{~kg}$ oleju bazowego $\mathrm{z}$ regenerowanych olejów przepracowanych, wymaga około $1 / 3$ mniej energii niż wyprodukowanie oleju bazowego z ropy naftowej.

Najbardziej opłacalny jest recykling materiałowy metali szlachetnych pochodzących z reaktorów katalitycznych. W produkcji pierwotnej w celu uzyskania 1 kg platynowców konieczne jest wydobycie około 
Oszczędność energii surowców pochodzących z recyklingu w stosunku do produkcji z surowców pierwotnych

Tablica 8

\begin{tabular}{|c|c|}
\hline Surowce & $\begin{array}{c}\text { Oszczędność energii } \\
{[\%]}\end{array}$ \\
\hline Aluminium & 95 \\
\hline Miedź & 85 \\
\hline Żelazo & 74 \\
\hline Ołów & 65 \\
\hline Polimery termoplastyczne & 60 \\
\hline Cynk & 60 \\
\hline
\end{tabular}

150 ton rudy z głębokości około $1000 \mathrm{~m}$.[8] Ruda ta oprócz platynowców ma dużą zawartość miedzi i niklu oraz innych metali, m.in.: chromu, żelaza, kobaltu, bizmutu, selenu, arsenu, telluru $\mathrm{w}$ postaci związków siarki. Podczas procesu wydobycia powstaje 400 ton odpadów i żużlu, które muszą być składowane i są bezużyteczne. Proces ten wymaga poza tym znacznych nakładów energii. $\mathrm{W}$ porównaniu $\mathrm{z}$ tym ilość metali szlachetnych uzyskiwana $\mathrm{z}$ reaktorów katalitycznych poddawanych odzyskowi jest bardzo duża. Na 2 tony reaktorów katalitycznych lub 0,5 tony nośników katalitycznych przypada $1 \mathrm{~kg}$ metali szlachetnych. Odzyskany materiał nie wymaga dalszego kosztownego przetwarzania. W tym przypadku recykling pozwala uniknąc dużych nakładów energii na produkcję, a emisja zanieczyszczeń podczas procesu jest wielokrotnie mniejsza w porównaniu $\mathrm{z}$ wydobyciem w kopalniach.

W przypadku stali wysoki wskaźnik odzysku wynika $\mathrm{z}$ tego, że złom pochodzący $\mathrm{z}$ odzysku jest głównym składnikiem przy produkcji nowej stali. Dzięki stosowaniu złomu zużywa się zaledwie 1/4 energii niezbędnej do produkcji stali na bazie rudy żelaza. Recykling 1 tony stali pozwala na zaoszczędzenie $1130 \mathrm{~kg}$ rudy żelaza, $635 \mathrm{~kg}$ węgla oraz $55 \mathrm{~kg}$ wapnia.

\section{Podsumowanie}

Do budowy środków transportu stosowane są różne materiały metalowe i niemetalowe. O zastosowaniu konkretnego materiału decyduja przede wszystkim jego właściwości, cena, ale także to, jakie skutki dla środowiska niesie za sobą jego produkcja, użytkowanie oraz likwidacja. Przeznacza się zatem coraz większe środki na badania i rozwój materiałów konstrukcyjnych. Dąży się m.in. do: potanienia dotychczas stosowanych materiałów; oszczędności energii przez doskonalenie procesów spalania paliwa wymagającego wyższych obciążeń cieplnych, co wymaga materiałów o dobrych właściwościach w wyższych temperaturach pracy; wytwarzania materiałów nie występujących w przyrodzie, np. kompozytów składających się z włókien węglowych $\mathrm{w}$ osnowie z żywicy epoksydowej; tworzenia materiałów przyjaznych środowisku, odnawialnych lub możliwych do powtórnego wykorzystania; tworzenia materiałów umożliwiających wytwarzanie wyrobów i energii w sposób przyjazny dla środowiska, np. produkcja specjalnych stali do budowy urządzeń.

Nowo powstające materiały są coraz bardziej ekologiczne z różnych względów. Ekologiczna może być ich produkcja, sposób recyklingu i ponowne wykorzystanie. Wśród nowoczesnych materiałów pojawiających się w produkcji pojazdów obserwuje się rosnący udział szczególnie tworzyw sztucznych polimerów, a także coraz ciekawszych kompozytów, stopów lekkich na bazie aluminium i magnezu oraz najnowszych nanomateriałów.

Coraz większe wymagania stawiane przed przemysłem środków transportu drogowego i szynowego w zakresie ekologii skłaniają do pracy nad projektowaniem takich materiałów, które zapewnią nie tylko lepsze właściwości trakcyjne czy większy komfort jazdy pojazdów, ale spowodują ograniczenie ich negatywnego oddziaływania na środowisko, również z ograniczeniem zużywanej energii na etapie ich wytwarzania oraz w całym okresie eksploatacji.

\section{Literatura}

[1] Dobrzański L., Materiały inżynierskie i projektowanie materiałowe. WNT; Warszawa 2006.

[2] Frost \& Sullivan, Zmniejszenie zużycia paliwa bodźcem do zastosowania lekkich materiałów w przemyśle motoryzacyjnym. www.frost.com (dostęp 22.09.2011).

[3] Herres N., Auswahl von Werkstoffen für den Leichtbau. Innovationstagung HSR Repperswill; Juni 2008.

[4] Klein B., Leichtbau-Konstruktion. 8 Aufl. Vieweg + Teubner; Wiesbaden 2009.

[5] Mayes S.J., Micromechanics Based Failure Analysis of Composite Structural Laminates; Naval Surface Warfare Center; Carderock Division 1999.

[6] Marciniak Z., Pielecha I., Pielecha J.; Przeglad $i$ wymagania dla lekkich materiałów konstrukcyjnych o minimalnym oddziaływaniu na środowisko naturalne, OR-10174. Praca niepublikowana IPS „,Tabor” w Poznaniu, 05.2012.

[7] Mazumdar S.K., Composites Manufacturing, Materials, Product and Process Engineering; CRC Press 2002.

[8] Merkisz J., Fuć P., Możliwości recyklingu samochodowych reaktorów katalitycznych; Materiaty II Międzynarodowej Konferencji Naukowo-Technicznej „Problemy Recyklingu”, Rogów 2002.

[9] Ochelski S., Metody doświadczalne mechaniki kompozytów konstrukcyjnych. WNT; Warszawa 2004.

[10] Oczoś K.E., Konstrukcje lekkie - istota, rodzaje, realizacja i zastosowanie. Cz. 1;Miesięcznik Naukowo-Techniczny Mechanik, nr 4, 2011.

[11] Vasiliev V.V., Morozov E.V.; Mechanics and Analysis of Composite Materials; Elsevier 2001.

[12] www.collano.com/e/markt/sandwich/index.php?navid $=26$ (dostep: : 27.03.2012).

[13] www.fibre-reinforced-plastic.com/2010/12/sandwichcomposite-and-core-material.html (dostęp: 21.03.2012). 